communication skills for couples and families, parenting, and many others. Recent advances have added anxiety management training, cognitive therapy, and training in problem solving.

Many programmes - both for patients and for professionals -have now been evaluated. ${ }^{9}$ The consensus is that short term gains are easy to obtain but maintaining the skills and generalising them to new circumstances are difficult. Researchers have now, however, developed pointers for improving the effectiveness of social skills training. One is to teach not only the skills themselves but also the competence to generate new skills. This includes training in how to improve perception of social cues and effective performances by others; how to select and implement alternative responses; and how to overcome emotional and cognitive blocks.

Social skills training is becoming increasingly available in the National Health Service and social services and is available togeneral practitioners mainly through departments of clinical psychology, community based hostels, and jointly organised community teams. Such services are currently being set up - for example, in Solihull as part of the joint National Demonstration Service in Rehabilitation. These services can accept not only patients with acute problems - such as social anxiety, depression, and addiction disorders -but also those with chronic problems, including schizophrenia and mental handicap.

\section{Peter Trower}

Top Grade Psychologist,

Middlefield Mental Handicap Unit,

Knowle,

West Midlands B93 0PX

1 Hollin CH, Trower P. Handbook of social skills training. Oxford: Pergamon Press, 1986.

2 Argyle M, Henderson M. The anatomy of relationships. Harmondsworth: Penguin, 1985.

3 Rook KS. Promoting social bonding. Am Psychol 1984;39:1389-407.

4 Argyle M. Social skills and health. London: Methuen, 1981.

5 Kagan CM. Interpersonal skills in nursing: Beckenham: Croom Helm, 1985.

6 Maguire P. Training health professionals in essential interviewing skills. In: Hollin CR, Trower PE, eds. Handbook of social skills training. Oxford: Pergamon, 1986.

7 Argyle $M$, Kendon $A$. The experimental analysis of social performance. In: Berkowitz L, ed. Advances in experimental social psychology. Vol 3. New York: Academic Press, 1967:55-98.

8 Trower P, Bryant BM, Argyle M. Social skills and mental health. London: Methuen, 1978.

9 Hollin CH, Trower P. Development and applications of social skills training: a review and critique. In: Hersen M, Eisler RM, Miller PM, eds. Progress in behavior modification. Vol 7: New York: Sage (in press).

\title{
A poor start for the Health Education Authority
}

What is depressing about the members of the new Health Education Authority (p 710) is not only the connection with tobacco manufacturers and brewers (28 February, $p$ 565) but also the kind of people they are-and the kind of people they are not. ${ }^{1}$ Where are the public health experts, the nutritionists, the epidemiologists, the social scientists, the experts in health promotion, the statisticians, and the community physicians? What we have instead are representatives of marketeers, a "personality," a broadcaster, and a personnel manager leavened with an expert on infectious diseases, a professor of psychiatry, a community nurse, and a general practitioner. The balance is wrong: more front line troops are needed. The odd marketeer may be useful, but the exclusion of experts from evaluative disciplines is a mistake-as is the reported disbanding of the present council's advisory bodies such as the Joint Advisory Committee on Nutrition Education. ${ }^{2}$

Possibly Mr Norman Fowler may argue that he does not want any experts on health promotion or environmental disease on the Health Education Authority but that the authority will consult such experts on an ad hoc basis. We believe he is mistaken: surely it will be the HEA that decides broad issues of policy, and the more knowledgeable its members the better.

Our other cause for concern is the government's readiness to ignore or reject the opinions of its advisers and expert committees. ${ }^{34}$ When medical and social scientists told the government that its campaigns on heroin and on AIDS had been less than wholly successful ${ }^{56}$ it responded by quoting the results of unconvincing evaluations. For example, in the opinion of one academic the evaluation of the heroin campaign was designed so poorly that neither the claims of success nor the allegations of failure could be proved (or disproved).

By now Mr Fowler should have got the message that campaigns must be evaluated, but will his new HEA commission the rigorous evaluations that are needed? Or will the experts he has assembled content themselves with superficial impressionistic assessments? The best market research is as disciplined as the best science-but both may come up with answers embarrassing to the establishment, as seems to be happening with leukaemia and nuclear power. . $^{8-10}$ Somehow scientific authorities with established reputations in campaign evaluation need to be recruited to oversee future health promotion. Their absence from the HEA has eroded its independence even before it begins work-because such skill is essential to underpin independence.

Assistant editor, $B M \mathcal{F}$

RICHARD SMITH

1 Anonymous. A mockery of health promotion. Lancet 1987;i:489.

2 Veitch A. Thirteen health watchdogs face axe. Guardian 1987 March 4:4

3 Anonymous. An endangered species. Br Med $\mathcal{F} 1980 ; 281: 1662-3$.

4 Anonymous. Rejecting scientific advice. BrMed f 1982;284:1426.

5 Anonymous. Media drug campaigns may be worse than a waste of money. BrMed f 1985;290:416.

Hansen A. Will the government's mass media campaign on drugs work? Br Med $\mathcal{f}$ 1985;290: 1054-5.

7 Marsh C. Medicine and the media. BrMed f 1986;292:953.

8 Black D. New evidence on childhood leukaemia and nuclear establishments. $\mathrm{Br}$ Med $\mathcal{f}$ 1987;294:591-2.

9 Roman E, Beral V, Carpenter L, et al. Childhood leukaemia in the West Berkshire and Basingstoke and North Hampshire District Health Authorities in relation to nuclear establishments in the vicinity. BrMed $\mathcal{F}$ 1987;294:597-602.

10 Darby SC, Doll R. Fallout, radiation doses near Dounreay, and childhood leukaemia. Br Med $\mathrm{J}$ 1987;294:603-8. 